\title{
Development of Canadian Safety Indicators for Medication Use
}

\author{
Rita Nigam, Neil J. MacKinnon, David U, Nicole R. Hartnell, Adrian R. Levy, Mary Ellen Gurnham and Tiffany T. Nguyen
}

\begin{abstract}
Reports of preventable illness due to medication errors are widespread in Canada. However, quantifying the magnitude of the problem has been hampered by a lack of measurement tools. Canadian-specific indicators, or performance measures, of safe medication use do not exist. The objective of this study was to develop a set of Canadian consensus-based indicators for the safe use of medication for both in-patient and outpatient settings.

A panel of 20 national experts was established from a convenience sample of experts representing medicine, nursing, pharmacy, research and decision-makers in hospitals and community settings across Canada. After creating a list of potential indicators from the literature, the final consensus set was chosen by the panel using a Delphi survey process via e-mail.

After three rounds, consensus was obtained on 20 medication-use safety indicators: seven indicators were related to systems of care, five to prescribing/ordering, three to monitoring/assessment, three to medication administration, one to preparation and dispensing and one to purchasing/inventory management. Seventeen of the indicators measure a process of care (in contrast to health outcome); at least 10 have applications outside the in-patient setting.

The resulting 20 medication-use safety indicators are diverse in scope and should be applicable in a variety of practice settings. These indicators may provide clinicians and decision-makers with valuable tools to assess the safety of medication-use systems.
\end{abstract}

\section{Background}

Patient safety is an area of increasing focus in Canada. Within this topic, safe use of medication has consistently been cited as a main area of concern; for example, both the Institute of Medicine report To Err Is Human (Kohn et al. 1999) and "The Canadian Adverse Events Study" (Baker et al. 2004) highlighted problems with adverse drug events. More recently, a special report on medication safety from the Institute of Medicine revealed that approximately 1.5 million preventable adverse drug events occur annually in the United States, resulting in a total cost of US\$3.5 billion (Aspden 2006). Patients also recognize problems with the medication-use system. In the 2002 Commonwealth Fund survey, $11 \%$ of patients in Canada reported that they had been given the wrong medication at one time or another (Schoen et al. 2003).

\section{Approximately 1.5 million preventable} adverse drug events occur annually in the United States, resulting in a total cost of US\$3.5 billion.

An indicator is a quantitative measure of some aspect of patient care that can be used to assess the quality of care being provided. Indicators are not direct measures of quality; they can be viewed as "alerts" to potential problems that require more detailed analysis (Nadzam 1991). Given the importance of medications in modern medicine, the fact that they are the fastest rising healthcare expenditure in Canada and that problems in their use have been widely documented, it is essential to use indicators to assess the medication-use system for both in-patient and outpatient settings. 
The medication-use system encompasses the typical course of action related to drug therapy, including ongoing monitoring of patient care and progress (Ackroyd-Stolarz et al. 2005). The stages in the system include prescribing, dispensing, administering and monitoring. Currently, there is no set of indicators for assessing this system that are uniquely fitted to the Canadian environment. As a consequence, performance evaluation and benchmarking of medication safety based on quantitative data are difficult. Furthermore, Canadian medication safety experts should have the opportunity to suggest new indicators. Therefore, the objective of this study was to generate a Canadian set of medication-use safety indicators based on consensus among experts in patient and medication safety.

\section{Methods}

The following steps were used to generate a Canadian set of medication-use safety indicators: establishing an expert panel, developing a survey for the indicators and using the Delphi technique to achieve consensus on the indicators. These steps are outlined in detail below.

\section{Expert Panel}

The co-investigators and the partnering national organizations - Canadian Council on Health Services Accreditation, Canadian College of Health Service Executives, Canadian Institute for Health Information, Canadian Pharmacists Association, Canadian Society of Hospital Pharmacists and the Institute for Safe Medication Practices Canada - were responsible for identifying nationally recognized experts in the safety of the medication-use system. An attempt was made to ensure that the panel had representation from across the country and from a variety of health professions and backgrounds. The 20 potential panellists who were identified were initially contacted by e-mail; they received a brief description of the study and what would be required of participants. Panellists were selected based on their experience, willingness to participate and availability. All 20 potential panellists asked agreed to participate; the target size of 20 people was governed by resource constraints. The panel consisted of experts in medication safety representing medicine, nursing, pharmacy, research and decision-makers in hospital and community settings across Canada (Table 1).

Table 1. Demographic characteristics of the Canadian expert panel

\begin{tabular}{|c|c|c|c|c|c|c|}
\hline Characteristic & $\begin{array}{l}\text { Pharmacists } \\
(n=7)\end{array}$ & $\begin{array}{l}\text { Physicians } \\
(n=4)\end{array}$ & $\begin{array}{l}\text { Registered } \\
\text { Nurses }(n=1)\end{array}$ & $\begin{array}{l}\text { Researchers } \\
(n=5)\end{array}$ & $\begin{array}{l}\text { Decision- } \\
\text { Makers } \\
(n=3)\end{array}$ & $\begin{array}{l}\text { Total } \\
(n=20)\end{array}$ \\
\hline \multicolumn{7}{|l|}{ Gender (\%) } \\
\hline Female & $6(86)$ & - & - & $2(40)$ & $1(33)$ & $9(45)$ \\
\hline Male & $1(14)$ & $4(100)$ & $1(100)$ & $3(60)$ & $2(67)$ & $11(55)$ \\
\hline \multicolumn{7}{|l|}{ Primary practice setting (\%) } \\
\hline Tertiary hospital & $1(14)$ & $2(50)$ & - & $1(20)$ & $2(67)$ & $6(30)$ \\
\hline Community hospital & - & - & $1(100)$ & - & - & $1(5)$ \\
\hline Clinic & - & $1(25)$ & - & - & - & $1(5)$ \\
\hline Community pharmacy & $2(29)$ & - & - & - & - & $2(10)$ \\
\hline Academia & - & $1(25)$ & - & $3(60)$ & - & $4(20)$ \\
\hline Regional health authority & $1(14)$ & - & - & - & $1(33)$ & $2(10)$ \\
\hline National organization & $1(14)$ & - & - & $1(20)$ & - & $2(10)$ \\
\hline Other & $2(29)$ & - & - & - & - & $2(10)$ \\
\hline \multicolumn{7}{|l|}{ Region (\%) } \\
\hline Atlantic & $1(14)$ & $1(25)$ & $1(100)$ & - & $1(33)$ & $4(20)$ \\
\hline Quebec & - & $2(50)$ & - & - & - & $2(10)$ \\
\hline Ontario & $1(14)$ & $1(25)$ & - & $4(80)$ & - & $6(30)$ \\
\hline Prairies & $1(14)$ & - & - & $1(20)$ & - & $2(10)$ \\
\hline British Columbia & $3(44)$ & - & - & - & $2(67)$ & $5(25)$ \\
\hline Northern territories & $1(14)$ & - & - & - & - & $1(5)$ \\
\hline \multicolumn{7}{|l|}{ Education (\%) } \\
\hline MD & - & $4(100)$ & - & - & - & $4(20)$ \\
\hline $\mathrm{PhD}$ & - & - & - & $2(40)$ & - & $2(10)$ \\
\hline PharmD & $1(14)$ & - & - & $2(40)$ & $1(33)$ & $4(20)$ \\
\hline MSc & $2(29)$ & - & - & $1(20)$ & $1(33)$ & $4(20)$ \\
\hline $\mathrm{BSc}$ & $4(57)$ & - & $1(100)$ & & $1(33)$ & $6(30)$ \\
\hline
\end{tabular}




\section{Survey Development}

The first step in the development of the survey was to search the literature. A MEDLINE search using the key words patient safety and medication errors produced 494 articles, which were reviewed by the lead author. Unpublished literature, which included information from organizations involved in medication safety, was also reviewed by the lead author. The indicators were developed by the two lead authors based on areas of concerns within the medication-use system discussed in both published and unpublished literature. The indicators were then classified according to stages in the medication-use system outlined by the Wisconsin Patient Safety Institute (2002). Indicators were assigned to one of the following six categories: prescribing/ordering, preparation and dispensing, administration, monitoring/assessment, purchasing/inventory management and systems of care (i.e., continuity of care after in-patient discharge). A draft survey instrument was created and pilot tested by the four co-investigators and five colleagues, who had the opportunity to comment on and suggest additional indicators. The co-investigators and colleagues consisted of experts in medication safety, physicians, nurses, pharmacists and researchers.

\section{Consensus Building}

We used the Delphi technique, which is a multiple iteration survey technique that enables anonymous, systematic refinement of expert opinion, to arrive at a combined or consensual opinion in a short period of time (Goodman 1987). It was first developed to prevent dominant personalities from taking over or intimidating others, as usually happens when groups of experts meet in person. The technique has been used extensively with expert panels to generate consensus on healthcare issues (Campbell and Cantrill 2001; Goodman 1987; Robertson and MacKinnon 2002). The experience of our research team suggests that in similar surveys using the Delphi technique, three or four rounds are typically required to reach consensus. In this study, the survey was distributed by e-mail; therefore, the participants never had the opportunity to meet in person, rendering the consensus process free of strong-personality coercion.

\section{Criteria for \\ Consensus}

Surveys were distributed via e-mail. Participants were asked, "Should this indicator be included in a national set of medication safety indicators?" Each panellist ranked the poten-

Table 2. Delphi rounds tial indicators on a five-point Likert scale, where $1=$ strongly disagree, $2=$ disagree, $3=$ unsure, $4=$ agree and $5=$ strongly agree. If the panellists chose 1 or 2 , they were asked to explain why they did not think that indicator should be included. In round one, experts had the opportunity to comment on indicators and suggest additional ones, which were then added for the next round. The mean score for each indicator was calculated, and a second survey was prepared, rendering anonymous all comments and suggestions of panellists.

Consistent with the Delphi technique, surveys were individually tailored so that each respondent received his or her score for each indicator on the previous round as well as the mean score of the group. The cut-offs for rounds one, two and three were $>4.0$ (agree or strongly agree) for achieving consensus approval. The cut-off for achieving consensus dropped for round one was $<2.0$, for round two was $\leq 3.5$ and for round three was $\leq 4.0$. The rationale for the standard for achieving consensus dropped is outlined in the results.

\section{Applications outside the in-patient setting are important as evidence shows that the rate of adverse events is four times higher in the community.}

\section{Results}

From the literature review and after the pilot test, 53 potential indicators were chosen for inclusion in the first round of the survey. After the responses from round one were collated, 16 indicators had a mean score $>4.0$ and were thus deemed to be consensus approved. In round two, 70 indicators were presented, including new indicators created based on panellists' comments and new indicators suggested by the panellists. Of these, one indicator had a mean score $>4.0$ and was thus deemed to be consensus approved. The mean scores of the remaining indicators were between 2.0 and 4.0. Thus, to avoid repeating a

\begin{tabular}{|c|c|c|c|c|c|}
\hline $\begin{array}{l}\text { Delphi } \\
\text { Rounds* }\end{array}$ & $\begin{array}{l}\text { No. of } \\
\text { Indicators } \\
\text { Evaluated }\end{array}$ & $\begin{array}{l}\text { No. Achieving } \\
\text { Consensus } \\
\text { Approved }\end{array}$ & $\begin{array}{l}\text { No. Achieving } \\
\text { Consensus } \\
\text { Dropped }\end{array}$ & $\begin{array}{l}\text { No. Not Achieving } \\
\text { Consensus Going } \\
\text { to Next Round }\end{array}$ & $\begin{array}{l}\text { No. New } \\
\text { Indicators } \\
\text { Suggested† }\end{array}$ \\
\hline 1 & 53 & 16 & 0 & 37 & 33 \\
\hline 2 & 70 & 1 & 55 & 14 & NA \\
\hline 3 & 14 & 3 & 11 & 0 & NA \\
\hline
\end{tabular}


Table 3. The final medication-use safety indicators approved by consensus

\begin{tabular}{|c|c|c|c|c|}
\hline Category and Indicator & Definition & Type & Source & $\begin{array}{l}\text { Location } \\
\text { of Data }\end{array}$ \\
\hline \multicolumn{5}{|l|}{ Prescribing/Ordering } \\
\hline $\begin{array}{l}\text { 1. Frequency of potentially dangerous } \\
\text { medication abbreviations (based on } \\
\text { Institute for Safe Medication Practices } \\
\text { [ISMP]) (ISMP 2006a) }\end{array}$ & $\begin{array}{l}\text { Number of prescriptions/medication orders using } \\
\text { potentially dangerous medication abbreviations as a } \\
\text { percentage of all prescriptions/medication orders }\end{array}$ & Process & $\begin{array}{l}\text { Canadian Council } \\
\text { on Health Services } \\
\text { Accreditation (2006) }\end{array}$ & $A l^{*}$ \\
\hline $\begin{array}{l}\text { 2. Frequency of potentially dangerous } \\
\text { dose abbreviations (based on ISMP) } \\
\text { (ISMP 2006b) }\end{array}$ & $\begin{array}{l}\text { Number of prescriptions/medication orders using } \\
\text { potentially dangerous dose abbreviations as a } \\
\text { percentage of all prescriptions/medication orders }\end{array}$ & Process & $\begin{array}{l}\text { Canadian Council } \\
\text { on Health Services } \\
\text { Accreditation (2006) }\end{array}$ & All \\
\hline $\begin{array}{l}\text { 3. Frequency of ambiguous prescription } \\
\text { dosing instructions }\end{array}$ & $\begin{array}{l}\text { Number of prescriptions/medication orders with } \\
\text { "take as directed" as the only instruction for use as } \\
\text { a percentage of all prescriptions/medication orders }\end{array}$ & Process & $\begin{array}{l}\text { Wisconsin Patient Safety } \\
\text { Institute (2002) }\end{array}$ & All \\
\hline $\begin{array}{l}\text { 4. Frequency of incorrect prescription } \\
\text { dose designation, e.g., } 0.1 \text { (rather than } \\
\text {.1) or } 1 \text { (rather than 1.0) }\end{array}$ & $\begin{array}{l}\text { Number of prescriptions/medication orders } \\
\text { with incorrect leading and/or trailing zeros with } \\
\text { decimal points as a percentage of all prescriptions/ } \\
\text { medication orders }\end{array}$ & Process & $\begin{array}{l}\text { Wisconsin Patient Safety } \\
\text { Institute (2002) }\end{array}$ & All \\
\hline $\begin{array}{l}\text { 5. Dosing for pediatric (patients }<12 \\
\text { years) medications that have a narrow } \\
\text { therapeutic index (e.g., prednisone, } \\
\text { aminoglycosides, some antibiotics, } \\
\text { chemotherapy) }\end{array}$ & $\begin{array}{l}\text { Number of pediatric prescriptions for medications } \\
\text { with a narrow therapeutic index with dose/weight } \\
\text { calculations omitted as a percentage of all pediatric } \\
\text { prescriptions for medications with a narrow } \\
\text { therapeutic index }\end{array}$ & Process & $\begin{array}{l}\text { Wisconsin Patient Safety } \\
\text { Institute (2002) }\end{array}$ & $\begin{array}{l}\text { All, } \\
\text { except } \\
\text { nursing } \\
\text { homes }\end{array}$ \\
\hline \multicolumn{5}{|l|}{ Preparation and Dispensing } \\
\hline 6. Documentation of allergy status & $\begin{array}{l}\text { Number of patient profiles in which allergy status is } \\
\text { documented before dispensing the first prescription/ } \\
\text { medication order to the patient as a percentage of } \\
\text { all patient profiles }\end{array}$ & Process & $\begin{array}{l}\text { 2003/2004 Annual Report. } \\
\text { Hospital Pharmacy in } \\
\text { Canada: Medication Safety } \\
\text { (2004) }\end{array}$ & All \\
\hline \multicolumn{5}{|l|}{ Administration } \\
\hline $\begin{array}{l}\text { 7. Administering protocols for high- } \\
\text { alert prescription medications (i.e., } \\
\text { medications that bear heightened risk } \\
\text { of causing significant patient harm } \\
\text { when used in error, e.g., insulin and } \\
\text { heparin) }\end{array}$ & $\begin{array}{l}\text { Number of prescriptions/medication orders for high- } \\
\text { alert medications using an administering protocol as } \\
\text { a percentage of all prescriptions/medication orders } \\
\text { for high-alert medications }\end{array}$ & Process & $\begin{array}{l}\text { 2003/2004 Annual Report. } \\
\text { Hospital Pharmacy in } \\
\text { Canada: Medication Safety } \\
\text { (2004) }\end{array}$ & $\begin{array}{l}\text { Hospitals } \\
\text { and } \\
\text { clinics }\end{array}$ \\
\hline 8. Verification of high-alert prescriptions & $\begin{array}{l}\text { Number of prescriptions/medication orders for } \\
\text { high-alert medications that are double-checked and } \\
\text { documented (with initials) by pharmacist before } \\
\text { administration as a percentage of all prescriptions/ } \\
\text { medication orders for high-alert medications }\end{array}$ & Process & $\begin{array}{l}\text { 2003/2004 Annual Report. } \\
\text { Hospital Pharmacy in } \\
\text { Canada: Medication Safety } \\
\text { (2004) }\end{array}$ & $\begin{array}{l}\text { Hospitals } \\
\text { and } \\
\text { clinics }\end{array}$ \\
\hline $\begin{array}{l}\text { 9. Machine-readable coding systems for } \\
\text { administration }\end{array}$ & $\begin{array}{l}\text { Number of doses administered with machine- } \\
\text { readable coding (bar codes) as a percentage of all } \\
\text { doses administered }\end{array}$ & Process & $\begin{array}{l}\text { American Society } \\
\text { of Health-System } \\
\text { Pharmacists (2007) }\end{array}$ & Hospitals \\
\hline \multicolumn{5}{|l|}{ Monitoring/Assessment } \\
\hline 10. Rate of ADE-related hospitalizations & $\begin{array}{l}\text { Number of ADE-related hospitalizations as a } \\
\text { percentage of all hospitalizations }\end{array}$ & Outcome & $\begin{array}{l}\text { Mackinnon and McCaffery } \\
\text { (2004) }\end{array}$ & Hospitals \\
\hline 11. Rate of ADE-related ER visits & $\begin{array}{l}\text { Number ADE-related ER visits as a percentage of all } \\
\text { ER visits }\end{array}$ & Outcome & $\begin{array}{l}\text { Mackinnon and McCaffery } \\
\text { (2004) }\end{array}$ & Hospitals \\
\hline
\end{tabular}


Table 3. The final medication-use safety indicators approved by consensus Cont'd

\begin{tabular}{|c|c|c|c|c|}
\hline $\begin{array}{l}\text { 12. Monitoring and reducing ADEs by } \\
\text { assigning pharmacists on rounds }\end{array}$ & $\begin{array}{l}\text { Number of beds with daily pharmacist participation } \\
\text { in interdisciplinary direct patient care as a } \\
\text { percentage of all beds }\end{array}$ & Process & $\begin{array}{l}\text { 2003/2004 Annual Report. } \\
\text { Hospital Pharmacy in } \\
\text { Canada: Medication Safety } \\
\text { (2004) }\end{array}$ & Hospitals \\
\hline \multicolumn{5}{|l|}{ Purchasing/Inventory Management } \\
\hline $\begin{array}{l}\text { 13. Differentiation of high-alert } \\
\text { prescription medications (i.e., drugs } \\
\text { that bear heightened risk of causing } \\
\text { significant patient harm when used in } \\
\text { error) (ISMP 2006b) }\end{array}$ & $\begin{array}{l}\text { Number of high-alert prescription medications } \\
\text { that are differentiated from other medications } \\
\text { using flags, highlighting or some other system as a } \\
\text { percentage of all high-alert prescription medications }\end{array}$ & Process & $\begin{array}{l}\text { Wisconsin Patient Safety } \\
\text { Institute (2002) }\end{array}$ & $\begin{array}{l}\text { Hospitals } \\
\text { and } \\
\text { clinics }\end{array}$ \\
\hline \multicolumn{5}{|l|}{ Systems of Care } \\
\hline $\begin{array}{l}\text { 14. Medication histories for in- } \\
\text { patients with complex high-risk } \\
\text { regimens (i.e., challenging dosing } \\
\text { schedule or route of administration; } \\
\text { medication with documented } \\
\text { and significant drug interactions } \\
\text { polypharmacy; and medications with } \\
\text { a narrow therapeutic index, insulin, } \\
\text { antithrombotics, chemotherapy, etc.) }\end{array}$ & $\begin{array}{l}\text { Number of in-patients with complex high-risk } \\
\text { medication regimens whose medication history } \\
\text { was recorded on admission as a percentage of } \\
\text { all in-patients with complex high-risk medication } \\
\text { regimens on admission }\end{array}$ & Process & $\begin{array}{l}\text { American Society } \\
\text { of Health-System } \\
\text { Pharmacists (2007) }\end{array}$ & $\begin{array}{l}\text { Hospitals, } \\
\text { clinics } \\
\text { and } \\
\text { nursing } \\
\text { homes }\end{array}$ \\
\hline 15. Medication reconciliationt rate & $\begin{array}{l}\text { Number of unintentional medication order } \\
\text { discrepancies (e.g., omission, commission, incorrect } \\
\text { dose, incorrect frequency) as a percentage of all } \\
\text { medication orders }\end{array}$ & Outcome & $\begin{array}{l}\text { Canadian Council } \\
\text { on Health Services } \\
\text { Accreditation (2006) }\end{array}$ & Hospitals \\
\hline $\begin{array}{l}\text { 16. Medication reconciliationt rate upon } \\
\text { admission }\end{array}$ & $\begin{array}{l}\text { Number of patients whose medication profiles } \\
\text { are reconciled within } 24 \text { hours of admission as a } \\
\text { percentage of admitted patients }\end{array}$ & Process & $\begin{array}{l}\text { Canadian Council } \\
\text { on Health Services } \\
\text { Accreditation (2006) }\end{array}$ & Hospitals \\
\hline $\begin{array}{l}\text { 17. Medication reconciliationt rate prior } \\
\text { to discharge }\end{array}$ & $\begin{array}{l}\text { Number of patients whose medication profiles are } \\
\text { reconciled within } 24 \text { hours before hospital discharge } \\
\text { as a percentage of discharged patients }\end{array}$ & Process & $\begin{array}{l}\text { Canadian Council } \\
\text { on Health Services } \\
\text { Accreditation (2006) }\end{array}$ & Hospitals \\
\hline $\begin{array}{l}\text { 18. Timeliness of discharge medication } \\
\text { summary sent to community } \\
\text { physicians }\end{array}$ & $\begin{array}{l}\text { Number of discharge medication summaries sent to } \\
\text { community physicians within } 72 \text { hours of hospital } \\
\text { discharge as a percentage of discharged patients on } \\
\text { medications }\end{array}$ & Process & $\begin{array}{l}\text { Canadian Council } \\
\text { on Health Services } \\
\text { Accreditation (2006) }\end{array}$ & Hospitals \\
\hline $\begin{array}{l}\text { 19. Timeliness of discharge medication } \\
\text { summaries sent to community } \\
\text { pharmacists }\end{array}$ & $\begin{array}{l}\text { Number of discharge medication summaries sent to } \\
\text { a community pharmacy within } 72 \text { hours of hospital } \\
\text { discharge as a percentage of discharged patients on } \\
\text { medications }\end{array}$ & Process & $\begin{array}{l}\text { Canadian Council } \\
\text { on Health Services } \\
\text { Accreditation (2006) }\end{array}$ & Hospitals \\
\hline $\begin{array}{l}\text { 20. Safety of compounding sterile } \\
\text { medications }\end{array}$ & $\begin{array}{l}\text { Number of hospitals that conduct an annual } \\
\text { assessment of the processes used for compounding } \\
\text { sterile medications (i.e., chemotherapy, intravenous } \\
\text { medications) as a percentage of hospitals }\end{array}$ & Process & $\begin{array}{l}\text { American Society } \\
\text { of Health-System } \\
\text { Pharmacists (2007) }\end{array}$ & Hospitals \\
\hline
\end{tabular}

$\mathrm{ADE}=$ adverse drug event; $\mathrm{ER}=$ emergency room.

${ }^{*}$ All refers to hospitals, clinics, community physician practices and offices, community pharmacies and nursing homes.

†A process that ensures the collection and communication of accurate patient/client medication information. The goal is to facilitate continuity of pharmaceutical care for patients/clients from admission to discharge or from beginning to end of service. 
review of all 69 indicators, for round three, only the 14 indicators with a mean score between 3.5 and 4.0 were presented to the panel. Of these, only three had a mean score $>4.0$ and were thus deemed to be consensus approved. The remaining 11 indicators were dropped since most of the indicators had already been in the survey for two rounds. Since consensus was not achieved by that point, the two lead authors felt it would never be achieved. Therefore, 20 indicators in total were consensus approved (mean score $>4.0$ ) after three Delphi rounds (Table 2). Consensus was achieved over a two-month period.

Of the 20 approved indicators, seven are related to systems of care, five to prescribing/ordering, three to monitoring/assessment, three to medication administration, one to preparing and dispensing and one to purchasing/inventory management. Seventeen of the indicators measure a process of care (in contrast to a health outcome); at least 10 have applications outside the in-patient setting (Table 3).

\section{Discussion}

Although medication safety indicators can be found in the literature (2003/2004 Annual Report. Hospital Pharmacy in Canada: Medication Safety 2004; Agency for Healthcare Research and Quality 2005; American Society of Health-System Pharmacists 2007; Canadian Council on Health Services Accreditation 2006; MacKinnon and McCaffery 2004; Nadzam 1991; Robertson and MacKinnon 2002), there is clearly room for additional indicators, especially those developed specifically for the Canadian healthcare environment. The 20 final medicationuse safety indicators on which our panel of experts agreed are quite diverse in scope and should be applicable in a variety of practice settings, including those outside the in-patient environment. The indicators generated in this study reflect the various stages in the medication-use system.

Safety is a concern at all these stages. Leape et al. (1995) found that most adverse drug events (ADEs) occur during the ordering and administration stages (39\% and 38\%, respectively); $12 \%$ occur during the transcription and verification stage and $11 \%$ during the pharmacy dispensing stage. Bates et al. (1995) had similar results: of the ADEs that were considered preventable, $49 \%$ occurred during the ordering stages, $26 \%$ during the administration stage, $11 \%$ during the transcription stage and $14 \%$ during the dispensing stage.

Our study focused on developing medication-use safety indicators that could be widely used in assessing quality of care in both hospital and community settings once they are validated. At least 10 of the indicators have applications outside the in-patient setting, which is important as evidence shows that the rate of adverse events is four times higher in the community (Gandhi et al. 2003). Forster et al. (2004) found that $23 \%$ of patients experienced an adverse event after discharge from hospital; $72 \%$ of these were attributable to medications.
Nickerson et al. (2005) determined that patients averaged 3.5 drug-related problems at the time of hospital discharge. Thus, the indicators developed in this study reflect areas where problems occur in the delivery of medications and the ongoing monitoring of the patient in the community.

\section{Limitations}

The method used in this study has some limitations. The Delphi technique's ability to achieve consensus results, at least in part, from group interactions that occur anonymously, thus preventing domination by one or a few individuals, role playing or intimidation (Campbell and Cantrill 2001; Goodman 1987). Although this is clearly a strength of the technique, at times, we felt that some in-depth discussion, perhaps via videoconferencing or face-to-face meetings, would have been valuable. For example, consensus was deemed to have been achieved based on mean scores, but, occasionally, some experts' comments contradicted the mean scores (i.e., the majority agreed, but there was not absolute group agreement). Follow-up group interaction to resolve these discrepancies would have been interesting.

\section{Conclusion}

This study developed a set of 20 consensus-based medicationuse safety indicators. In a second phase, a subset of these indicators will be tested for feasibility, reliability and validity in four health authorities in Atlantic Canada. If these indicators are found to be feasible, reliable and valid, the national partnering organizations will be involved in a comprehensive dissemination and knowledge-transfer strategy to ensure that the indicators are widely used, providing clinicians and decision-makers alike with a valuable tool to assess the safety of the medication-use system in Canada. HQ

\section{About the Authors}

Rita Nigam, PhD, is a research associate at the College of Pharmacy, Dalhousie University, Halifax, Nova Scotia.

Neil J. MacKinnon, PhD, FCSHP, is the associate director for research and associate professor in the College of Pharmacy, and associate professor in the School of Health Services Administration and Department of Community Health and Epidemiology, Faculty of Medicine at Dalhousie University. You can reach Dr. MacKinnon at 902-494-6379, by fax at 902-4941396 or by e-mail at neil.mackinnon@dal.ca.

David U, MSc(Pharm), is president and chief executive officer of the Institute for Safe Medication Practices (ISMP) Canada, in Toronto, Ontario.

Nicole R. Hartnell, MSc(Pharm), PhD (candidate), is a research associate at the College of Pharmacy, Dalhousie University. 
Adrian R. Levy, PhD, is an associate professor in the Department of Health Care and Epidemiology, University of British Columbia, Vancouver, British Columbia.

Mary Ellen Gurnham, RN, is chief nursing officer and director of professional practice, Capital District Health Authority, Victoria General Site, Halifax, Nova Scotia.

Tiffany T. Nguyen is a research assistant, College of Pharmacy, Dalhousie University.

\section{Acknowledgements}

This study was funded by a grant from the Canadian Patient Safety Institute. Matching and in-kind support was provided by four partnering health authorities - Annapolis Valley District Health Authority (Nova Scotia), Capital District Health Authority (Nova Scotia), Eastern Regional Integrated Health Authority (Newfoundland and Labrador) and IWK Health Centre (Nova Scotia) - and six partnering national organizations: Canadian Council on Health Services Accreditation, Canadian College of Health Service Executives, Canadian Institute for Health Information, Canadian Pharmacists Association, Canadian Society of Hospital Pharmacists and the Institute for Safe Medication Practices Canada.

\section{References}

2003/2004 Annual Report. Hospital Pharmacy in Canada: Medication Safety. 2004. Toronto: Eli Lilly Canada Inc. Retrieved December 26, 2006. <www.lillyhospitalsurvey.ca/hpc2/content/rep_2004_toc.asp >.

Ackroyd-Stolarz, S., N. Hartnell and N.J. MacKinnon. 2005. "Approaches to Improving the Safety of the Medication Use System." Healthcare Quarterly 8: 59-64.

Agency for Healthcare Research and Quality. 2005. AHRQ Quality Indicators: Guide to Patient Safety Indicators (V. 2.1, Revision 3. Publication No. 03-R203). Rockville, MD: Author. Retrieved December 27, 2006. <www.qualityindicators.ahrq.gov/archives/psi/ psi_guide_rev3.pdf>.

American Society of Health-System Pharmacists. 2007. ASHP HealthSystem Pharmacy 2015 Initiative Self-Assessment Tool. Bethesda, MD: Author. Retrieved January 11, 2007. <www.ashp.org/s_ashp/quart1. asp?CID $=218 \& \mathrm{DID}=255>$.

Aspden, P., ed. 2006. Preventing Medication Errors. Washington: Institute of Medicine. Retrieved January 9, 2007. <www.iom.edu/ Object.File/Master/35/943/medication\%20errors\%20new.pdf>.

Baker, G.R., P.G. Norton, V. Flintoft, R. Blais, A. Brown, J. Cox, E. Etchells, W.A. Ghali, P. Hebert, S.R. Majumdar, M. O’Beirne, L. Palacios-Derflingher, R.J. Reid, S. Sheps and R. Tamblyn. 2004. "The Canadian Adverse Events Study: The Incidence of Adverse Events among Hospital Patients in Canada." Canadian Medical Association Journal 170(11): 1678-86.

Bates, D.W., D.J. Cullen, N. Laird, L.A. Petersen, S.D. Small, D. Servi, G. Laffel, B.J. Sweitzer, B.F. Shea, R. Hallisey et al. 1995. "Incidence of Adverse Drug Events and Potential Adverse Drug Events: Implications for Prevention. ADE Prevention Study Group." Journal of the American Medical Association 274(1): 29-34.
Campbell, S.M. and J.A. Cantrill. 2001. "Consensus Methods in Prescribing Research." Journal of Clinical Pharmacy and Therapeutics 26(1): 5-14.

Canadian Council on Health Services Accreditation. 2006. CCHSA Patient Safety-Canadian Performance Measures Consensus Survey: Summary Report for Participating Organizations. Ottawa: Author.

Forster, A.J., H.D. Clark, A. Menard, N. Dupuis, R. Chernish, N. Chandok, A. Khan and C. van Walraven. 2004. "Adverse Events among Medical Patients after Discharge from Hospital." Canadian Medical Association Journal 170(3): 345-49. Retrieved December 27, 2006. <www.cmaj.ca/cgi/content/full/170/3/345>.

Gandhi, T.K., S.N. Weingart, J. Borus, A.C. Seger, J. Peterson, E. Burdick, D.L. Seger, K. Shu, F. Federico, L.L. Leape and D.W. Bates. 2003. "Adverse Drug Events in Ambulatory Care." New England Journal of Medicine 348(16): 1556-64.

Goodman, C.M. 1987. “The Delphi Technique: A Critique.” Journal of Advanced Nursing 12(6): 729-34.

Institute for Safe Medication Practices. 2006a. ISMP's List of ErrorProne Abbreviations, Symbols, and Dose Designations. Huntingdon Valley, PA: Author. Retrieved December 29, 2006. <www.ismp.org/ Tools/errorproneabbreviations.pdf $>$.

Institute for Safe Medication Practices. 2006b. ISMP's List of High-Alert Medications. Huntingdon Valley, PA: Author. Retrieved December 29, 2006. <www.ismp.org/Tools/highalertmedications.pdf>.

Kohn, L.T., J.M. Corrigan and M.S. Donaldson, eds. 1999. To Err Is Human: Building a Safer Health System. Washington, DC: Institute of Medicine, National Academy Press.

Leape, L.L., D.W. Bates, D.J. Cullen, J. Cooper, H.J. Demonaco, T. Gallivan, R. Hallisey, J. Ives, N. Laird, G. Laffel et al. 1995. "Systems Analysis of Adverse Drug Events. ADE Prevention Study Group." Journal of the American Medical Association 274(1): 35-43.

MacKinnon, N.J. and K.J. McCaffery. 2004. Health System Performance Indicator as a Tool for Maximizing Health Gains in Canada: Where Do Pharmaceuticals Fit? Kirkland, QC: Merck Frosst Canada Ltd.

Nadzam, D.M. 1991. "Development of Medication-Use Indicators by the Joint Commission on Accreditation of Healthcare Organizations." American Journal of Hospital Pharmacy 48(9): 1925-30.

Nickerson, A., N.J. MacKinnon, N. Roberts and L. Saulnier. 2005. "Drug-Therapy Problems, Inconsistencies and Omissions Identified during a Medication Reconciliation and Seamless Care Service." Healthcare Quarterly 8: 65-72.

Robertson, H.A. and N.J. MacKinnon. 2002. "Development of a List of Consensus-Approved Clinical Indicators of Preventable DrugRelated Morbidity in Older Adults." Clinical Therapeutics 24(10): 1595-613.

Schoen, C., C. DesRoches and D. Downey. 2003. The Canadian Health Care System: Views and Experiences of Adults with Health Problems. New York: The Commonwealth Fund.

Wisconsin Patient Safety Institute. 2002. Maximizing Patient Safety in the Medication Use Process: Practice Guidelines and Best Demonstrated Practices. Madison, WI: Author. 